University of Pennsylvania Carey Law School

Penn Law: Legal Scholarship Repository

Faculty Scholarship at Penn Law

$11-1-2005$

\title{
Tradable Pollution Permits and the Regulatory Game
}

Jason S. Johnston

University of Pennsylvania Carey Law School

Follow this and additional works at: https://scholarship.law.upenn.edu/faculty_scholarship

Part of the Administrative Law Commons, Environmental Law Commons, and the Law and Economics Commons

\section{Repository Citation}

Johnston, Jason S., "Tradable Pollution Permits and the Regulatory Game" (2005). Faculty Scholarship at Penn Law. 90.

https://scholarship.law.upenn.edu/faculty_scholarship/90

This Article is brought to you for free and open access by Penn Law: Legal Scholarship Repository. It has been accepted for inclusion in Faculty Scholarship at Penn Law by an authorized administrator of Penn Law: Legal Scholarship Repository. For more information, please contact PennlawIR@law.upenn.edu. 


\title{
Tradable Pollution Permits and the Regulatory Game
}

\author{
Jason Scott Johnston* \\ Robert G. Fuller, Jr. Professor of Law and \\ Director, Program on Law and the Environment \\ University of Pennsylvania Law School \\ 3400 Chestnut Street \\ Philadelphia, PA 19104-6204 \\ Ph: 215-898-6911 \\ E-Mail: jjohnsto@law.upenn.edu
}

November, 2005

\begin{abstract}
This paper analyzes polluters' incentives to move from a traditional command and control (CAC) environmental regulatory regime to a tradable permits (TPP) regime. Existing work in environmental economics does not model how firms contest and bargain over actual regulatory implementation in CAC regimes, and therefore fail to compare TPP regimes with any CAC regime that is actually observed. This paper models CAC environmental regulation as a bargaining game over
\end{abstract}

*I am grateful to the editors for helpful comments and suggestions, and to all of the participants in the August, 2003 UC Santa Barbara workshop for stimulating discussion after presentation of the initial draft of these ideas, and especially to Juan Pablo Montero and Nathaniel Keohane for suggestions on the more formal analysis. I received helpful comments on later versions of this paper from participants in the Law and Economics Workshop at the University of Chicago and the Agricultural and Resource Economics Department Colloquium at the University of Arizona. Doug Lichtman and Dean Lueck had especially helpful written comments and suggestions. I of course remain responsible for remaining errors. 
pollution entitlements. Using a reduced form model of the regulatory contest, it shows that CAC regulatory bargaining likely generates a regulatory status quo under which firms with the highest compliance costs bargain for the smallest pollution reductions, or even no reduction at all. As for a tradable permits regime, it is shown that all firms are better off under such a regime than they would be under an idealized CAC regime that set and enforced a uniform pollution standard, but permit sellers (low compliance cost firms) may actually be better off under a TPP regime with relaxed aggregate pollution levels. Most importantly, because high cost firms (or facilities) are the most weakly regulated in the equilibrium under negotiated or bargained $\mathrm{CAC}$ regimes, they may be net losers in a proposed move to a TPP regime. When equilibrium costs under a TPP regime are compared with equilibrium costs under a status quo CAC regime, several otherwise paradoxical aspects of firm attitudes toward TPP-type reforms can be explained. In particular, the otherwise paradoxical pattern of allowances awarded under Phase II of the 1990 Clean Air Act's acid rain program, a pattern tending to favor (in Phase II) cleaner, newer generating units, is explained by the fact that under the status quo regime, a kind of bargained $\mathrm{CAC}$, it was the newer cleaner units that were regulated, and which therefore had higher marginal control costs than did the largely unregulated older, plants. As a normative matter, the analysis here implies that the proper baseline for evaluating TPP regimes such as those contained in the Bush Administration's recent Clear Skies initiative is not idealized, but nonexistent CAC regulatory outcomes, but rather the outcomes that have resulted from the bargaining game set up by CAC laws and regulations.

\section{Introduction}

For over three decades, federal, state and local environmental regulators and the polluting industries that they regulate have been bargaining to reduce the amount of pollution put into Americas air, water and groundwater. They have done so pursuant to a set of federal statutes that by and large tell regulators to base pollution standards on what is technologically and economically achievable within various industry categories and subcategories. For decades, this regime which is known as command and control environmental regulation has been widely decried as inefficient. ${ }^{1}$ For an equally long time, economists have been advocating an alterntive regulatory regime, one

Johnston, Tradable Pollution Permits 
based on tradeable pollution permits (what I shall refer to as a TPP regime). TPP regimes set an overall, aggregate cap on the emissions of a particular pollutant and then allocate that aggregate cap among individual sources of the pollutant in the form of tradeable pollution permits. There is now a vast theoretical, empirical and experimental economics literature examining both positive issues regarding the actual operation of such markets, and normative questions involving when and whether such market mechanisms may improve social welfare relative to various benchmarks. ${ }^{2}$ Indeed, so powerful is the standard economic argument for TPP regimes that their relative scarcity in American environmental regulation ${ }^{3}$ now stands as something of an unexplained paradox. However, as shown by the relative success of sulfur dioxide permit trading under Title IV of the 1990 Clean Air Act, ${ }^{4}$ TPP regimes are more than just a theoretical possibility. TPP regimes have moreover been proposed recently as an instrument for limiting mercury, NOX and greenhouse gas emissions, as well as for controlling nutrient laden wastewaters in various watersheds. ${ }^{5}$

Economists have exhaustively analyzed the efficiency of incentives created by theoretical TPP regimes and, as other contributions to this volume show, they have also mounted sophisticated and illuminating ex post empirical analyses of the performance of the one large scale existing TPP regime in the U.S.(the Title IV acid rain trading program). Left underexplored, however, has been a very basic question of positive political economy, a question that is fundamental to explaining when TPP regimes are actually likely to move from theory to reality: Among polluting firms, who are the winners and losers in the move from command and control to a TPP regime? When will the majority of polluting firms support such a move and when will they not?

This article hopes to contribute toward an answer to these questions. In my view, a major reason why these questions have been neglected in the economic literature on TPP regimes is because analysts have generally worked with a highly oversimplified and unrealistic notion of what command and control regulation actually means for polluting firms. ${ }^{6}$ To understand this, one must understand not only a bit of the stylized history of late twentieth century American Environmentalism, but also the relatively arcane and complex world of the regulatory system that Environmentalism created. Both the legislative birth and regulatory elaboration of command and control pollution laws have clear and powerful political - economic explanations. I begin therefore with some general positive observations regarding the evolution of command and control environmental regulation in the United States, and

Johnston, Tradable Pollution Permits 
a brief but relatively detailed look at how laws and regulation have in fact shaped the command and control regulatory bargaining process.

I then develop a more formal analysis of the command and control regulatory bargaining process. While highly simplified, the model captures an important feature of regulatory bargaining: Whether through the initial (federal level) regulatory categorization process, or in bargaining with state and local permitting authorities, the higher is a firm's regulatory compliance cost, the more the firm has at stake in the regulatory game, and therefore the greater the resources that the firm will devote to fighting regulation and the lower is the actual regulatory burden imposed. The model predicts the widely observed but otherwise paradoxical phenomenon that under command and control regulation, it is usually those firms that have the highest compliance costs (firms with the oldest and dirtiest plants) who are regulated the least.

In order to discern winners and losers in a hypothetical transition from command and control (CAC) to a TPP regime, I compare the equilibrium distribution of firm costs under alternative versions of command and control to firm net costs under a TPP regime. Net costs under a TPP regime depend upon whether a particular firm is a buyer or seller of tradeable permits. Using a simple model of equilibrium in a TPP market, I show that for a given pollution reduction standard (permitted level of pollution) implementing that standard via a TPP regime will make both low and high compliance cost firms in an industry better off relative to idealized command and control (where every firm complies with the stated pollution reduction standard). Relative to equilibrium, firm-specific pollution reduction levels under bargained CAC, however, moving to a TPP regime is likely to make high compliance cost firms (permit buyers under TPP) worse off. With this result and others (such as that firm support for a move to a TPP regime depends upon such factors as permit demand elasticity and the stringency of the aggregate cap), the analysis helps explain why polluters sometimes do not support TPP regimes as well as why they sometimes do. It also suggests that the normative evaluation of TPP reform proposals should be based on realistic rather than idealized descriptions of the CAC system being reformed.

Johnston, Tradable Pollution Permits 


\section{The Evolution of Federal Command and Control Regulation}

The social problem underlying modern (that is, late twentieth century) American pollution control regulation was that publicly owned resources such as air and water were traditionally treated as free public goods, used as waste receptacles on a first-come-first-served basis. By the late 1960's, the post World War II boom in American manufacturing had accomplished two things that together created a national demand for environmental cleanup and control: the boom brought mass affluence and dramatic increases in leisure time, thus generating a new mass demand for outdoor recreation; on the other hand, so much waste had been put into American airsheds and waterways that those resources had been pushed to the point where they were either affirmatively dangerous to health or at the very least unsuitable for precisely the kinds of outdoor recreation that Americans demanded. On this view, which I elaborate in considerable detail elsewhere, ${ }^{7}$ the environmental problems that modern federal environmental legislation and regulation were designed to fix were decidedly local. Federal environmental regulation was designed to improve and protect air, surface water (and later, through $\mathrm{RCRA}^{8}$ and $\mathrm{CERCLA}^{9}$ ) groundwater quality so as to benefit people who resided near and therefore would be benefited most by such improvement and protection.

In other words, federal environmental regulation was designed to provide local environmental goods. The fact that American industrial polluters had no common law right to pollute is absolutely crucial in understanding why American environmental regulation took the form of technology-based command and control requirements rather than either TPP's or emission taxes. From the point of view of beneficiaries from pollution control, the fact that polluters did not have a common law right to use public resources meant that polluters could (legally if not as a matter of equilibrium cost distribution) be made to bear the entire cost of cutting pollution by installing costly pollution abatement technologies. From the point of view of pollution abatement beneficiaries, such a system seemed clearly preferable to one in which they paid polluters to abate their pollution. Of course, giving polluters a limited statutory right to pollute and making that right tradeable would not have necessarily entailed a payment to polluters. A system of tradeable rights is, however, based upon statutorily defined rights. Given that the status quo regime in a typical American industrial city as of, say 1965, was effectively an

Johnston, Tradable Pollution Permits 
unlimited right to pollute, moving from the status quo to a regime with very limited rights to pollute would have entailed enormous costs to American industry, to American workers and to the industrial heartland communities where such industries were located. Because the American government had actively encouraged and even subsidized the creation of the status quo regime, to drastically switch regimes would not only have been economically destructive, but in a very real sense unfair.

Rather than a dramatic switch in property rights regimes, the first generation of American federal environmental statutes attempt a relatively modest adjustment in rights. Today, the command and control regime created pursuant to these statutes is much decried. Such criticism exemplifies hindsight bias. Much to the contrary, given the level of sunk investments in plant and production processes and the existing technology that prevailed in the early 1970's, the first generation federal environmental laws approximate a market mimicking, value maximizing solution to the problem of pollution reduction. Although it is true that federal environmental statutes contain language suggesting a goal of zero pollution, ${ }^{10}$ those statutes are enormously (deliberately) complex. Read carefully and correctly, statutes such as the Clean Air and Clean Water Acts tell federal environmental regulators to reduce what had been an unlimited right to pollute, but to do so subject to the constraint that the economic and social cost of such reduction not rise to politically unacceptable levels. ${ }^{11}$ Unsurprisingly, such a mandate has been translated into a set of pollution control standards that look at what can be done to reduce pollution, given existing technological and economic realities. No one ever thought that these were clear and precise statutory mandates. Indeed, as I have argued elsewhere, the Congressional interest in environmental as in other similar regulatory legislation is to clearly endorse consensus goals while providing substantial discretion to regulators in how to realize those goals, thus enabling ad hoc Congressional intervention to prevent the regulatory imposition of politically unacceptable costs. ${ }^{12}$ Still, as of the early 1970's, with large and as yet unrealized investments in sunk industrial facilities, and very little known pollution abatement technology available, the command and control edict approximates what an informed observer might well have understood by a "reasonable" or net value maximizing approach to the problem of pollution reduction.

By cutting polluters' entitlements - from free and uncontrolled use of the air and waterways for waste disposal, to only those levels of disposal consistent with a reasonable investment in abatement technology - modern

Johnston, Tradable Pollution Permits 
environmental laws adjusted an analytically inevitable and historically everpresent bargaining game between polluters and government. Readjusting entitlements in this way is certainly no less a "market" response than would be the imposition of a tax on pollution. Indeed, a command and control regulatory regime may be understood merely as shifting the focus of bargaining between polluters and government - away from the magnitude of harm caused by pollution, which idealized pollution taxes capture - and toward how it is that polluters must seek to reduce that harm. Indeed, from a traditional law and economics perspective, the difference between pollution taxes and a readjustment in pollution entitlements through command and control may be usefully understood as the difference between a property rights approach under command and control versus a liability rule approach under pollution taxes. ${ }^{13}$ The property rights approach taken by command and control regulation cut back on what had been a relatively clear entitlement to pollute, limiting polluters' rights to that level of pollution consistent with statutorily required abatement efforts. By giving polluters the right to pollute as much as they wish, but charging them a tax equal to the harm caused by their pollution, taxes give the public a right to be free of pollution, but do not allow them to demand reductions in pollution below the levels induced by pollution taxes. They may thus be understood as recognizing a public right to be free of pollution, but allowing polluters to infringe that right so long as they pay the required price.

As a positive matter, it is relatively easy to see why first generation federal environmental regulation eschewed pollution taxes in favor of command and control. Pollution taxes might well have seemed attractive to beneficiaries from pollution reduction. Like command and control requirements, pollution taxes induce a reduction in pollution. Unlike command and control requirements, they compensate beneficiaries from pollution reduction for the continuing harm from reduced levels of pollution. Taxes would therefore seem preferable from a beneficiary point of view. By the same token, however, pollution taxes increase the cost of pollution control to polluters: in addition to the cost of reducing pollution that they would incur under a command and control regime, they also must pay for the harm caused by pollution that remains after compliance with the standard. ${ }^{14}$ Moreover, pollution taxes can work only if pollution is effectively monitored. As Stavins observes in his chapter in this volume, ${ }^{15}$ such monitoring is now possible for some pollutants and some industries, but was generally nonexistent when modern environmental laws were enacted. Monitoring pollution is, moreover, 
a minor problem compared with the problem of determining the magnitude of the tax. Pollution taxes anticipate the pollution will continue, albeit at reduced levels relative to a no-tax world. The economic ideal is to set pollution taxes equal to the level of actual harm caused by pollution. Monetizing the actual harm caused by pollution remains a highly imperfect and controversial process. Finally, and perhaps most importantly, although it is theoretically possible to understand pollution taxes as recognizing a public entitlement to be free of pollution but then allowing polluters to take that entitlement provided they pay compensation, it is equally possible to view pollution taxes as giving polluters a conditional entitlement to pollute. A fundamental political goal of late twentieth century American environmentalism was to change the status quo allocation of property rights, to declare that polluters did not have a right to pollute but rather the public had a right to be free of pollution, to move from one property rights regime to another. Inasmuch as pollution taxes can be interpreted as granting a conditional right to pollute, they were and remain inconsistent with this structural goal.

\section{What is Command and Control?: Some Examples of the Technology-Based Envi- ronmental Regulatory Regime}

In order to develop a sensible economic model of the regulatory bargaining game under command and control environmental regulation, it is necessary to describe, albeit briefly, what command and control regulation actually looks like. It is important to begin with a clear understanding of the precise sense in which uniform command and control regulation is uniform. Federal environmental laws (such as the Clean Air Act and Clean Water Act) that mandate technology-based regulatory standards do require uniform emissions reductions, but only for plants or facilities that are in the same industry category and which are of the same approximate age. Under the Clean Water Act, for instance, EPA promulgates five different kinds of technology-based standards for each of several hundred industry subcategories. ${ }^{16}$ Each effluent standard (or effluent guideline, as they are called under the CWA) sets a ceiling on a particular sort of source of pollution (or class of pollutants). The ceiling is EPA's belief - obtained from sampling existing facilities that have such sources, or independently, through modeling or from abatement

Johnston, Tradable Pollution Permits 
industry consultants - about the level of emissions reduction that a particular source category can achieve if they install a particular pollution control technology. New facilities (those constructed after the promulgation of the first set of CWA regulations) were required to meet the toughest standard, one based on the "best available demonstrated control technology. " ${ }^{\text {"17 }}$ Facilities in existence at the time that the CWA was passed were required to install the "best practicable control technology currently available by 1977 " (BPT) which in the case of "conventional pollutants" (such as organic, biological oxygen demanding and fecal coliform) meant "best conventional pollutant technology " $(\mathrm{BCT})^{18}$ and for other pollutants meant the "best available technology economically achievable." (BAT) $)^{19}$ The CWA instructs EPA to determine BPT limitations by considering "the total cost of application of technology in relation to the effluent reduction benefits to be achieved from such application," taking into account a variety of factors relating to production and effluent control technologies, non-water quality environmental impacts, and other factors deemed appropriate by EPA. ${ }^{20}$

In setting BPT and BCT - based emissions limits, ${ }^{21} \mathrm{EPA}$ first determines for each industry category or subcategory the level of control associated with the average of the best pollution control performance by exemplary plants of varying ages, sizes, and production processes. It then does what may be called a loose categorical (versus facility or source-specific) cost-benefit analysis. ${ }^{22}$ Under such an analysis - which is common to statutes mandating technology-based standards - the agency inquires into the significance of compliance costs as a share of industry total costs, and into whether those costs could be imposed without causing substantial economic dislocation, meaning firm closures. On the benefits side, the question for the agency was whether compliance with the standards would produce substantial progress toward the CWA's statutory goal of eliminating pollution discharges. ${ }^{23}$ Thus while both the "best practicable" and "best conventional" technological standards require EPA to take compliance costs into account, this is only an industry category basis. ${ }^{24}$ Even within a given industry category, however, no two facilities are exactly alike, not only in their physical layout, but also in the actual efficacy of any given pollution abatement technology. ${ }^{25}$ Early in the history of the CWA, industry argued that the statute obligated or at least permitted EPA to take individual, facility-specific costs and benefits into account in setting effluent guidelines. The Supreme Court rejected that argument, ${ }^{26}$ making it quite clear that EPA is to set technology-based standards that are indeed uniform within facilities of a given age and industrial

Johnston, Tradable Pollution Permits 
category.

A very similar regulatory structure pertains under the Clean Air Act. The Clean Air Act amendments of 1970 gave EPA the job of establishing National Ambient Air Quality Standards (NAAQS) for specific "criteria" pollutants in ambient air, but delegated to the states the task of coming up with State Implementation Plans (SIP's) that would achieve these standards by specific deadlines. The original 1970 CAA generally eschewed resort to technologybased standards, except for new sources of air pollution, for which EPA was required to establish emissions standards for different categories of pollution sources based on the "degree of emission limitation and the percentage reduction achievable through application of the best technological system of continuous emission reduction which (taking into consideration the cost of achieving such emission reduction, any nonair quality health and environmental impact and energy requirements) the Administrator determines has been adequately demonstrated." 27 Although the courts interpreted this provision to approve EPA's use of a variable standard for reducing sulfur dioxide emissions from coal burning power plants of between 70 and 90 per cent, depending upon the sulfur content of the fuel being used, ${ }^{28}$ they also declared that fuel switching alone was insufficient to satisfy the "best technological system" language of the new source performance standard. ${ }^{29}$ Thus although EPA has the statutory authority to subcategorize sources, ${ }^{30}$ the courts have upheld EPAs discretion to instead issue uniform standards for broad source categories. $^{31}$ Thus in practical effect, EPA has often interpreted new source performance standards to require some plants to adopt costly but unnecessary control technologies.

The federally determined, technology-based standards governing new sources were an exception to the general approach taken by the 1970 CAA amendments, which was to set national ambient air quality standards and then let the states figure out how to achieve those standards. Over the period 19701990, however, states consistently failed to achieve the NAAQS by statutory deadlines, and in many areas of the country, air quality actually worsened. In reaction, Congress in 1977 and 1990 substantially amended the CAA so that it is now, like the CWA, a statute that relies primarily upon uniform federal technology-based standards. In 1977, Congress specified that SIP's could allow new major sources of air pollution in nonattainment areas only if the new polluter met the "lowest achievable emissions rate" (LAER). ${ }^{32}$ LAER, which is generally determined on a case-by-case basis during preconstruction permit review, is defined by the CAA as the most stringent emission 
limitation contained in regulations applicable to that source, or the most stringent limitation that is achieved in practice for such source. ${ }^{33}$ For existing major sources, the 1977 amendments require that SIP's "provide for the implementation of all reasonably available control measures as expeditiously as is practicable" 34 and must in the meantime accomplish "such reductions in emissions from existing sources in the area as may be obtained through the adoption, at a minimum, or reasonably available control technology (RACT)." 35 In practice, both LAER and RACT have amounted to uniform technology-based standards determined by EPA from which SIP's cannot generally deviate. ${ }^{36}$ The 1990 amendments retained these technologybased standards and added some new ones, such as "generally achievable control technology," 37 and "best available control measures." 38 Moreover, the 1990 amendments clearly moved the CAA toward the CWA model by explicitly requiring permits for air pollution sources covered by the statute. ${ }^{39}$

For present purposes, the most important thing to see about technologybased emissions standards that are uniform within industry subcategories is that the standards are themselves the outcome of an intense bargaining process between environmental regulators and industry. Under both the CWA and CAA, EPA determines "best practicable, " "best available" and "reasonably available" technologies by securing technical analyses from engineering and economic consultants who sample actual industry practices and pilot projects. EPA's studies are then critiqued by industry during (and even before) the notice and comment period. The process of promulgating technology-based standards is a long, costly battle between industry and EPA over issues regarding the cost and effectiveness of a particular technology, and how these vary with facility type, and how these variations go into the initial decision of how to draw industry categories and subcategories. ${ }^{40}$ Time and time again, industry has persuaded EPA to withdraw proposed standards by arguing that the standards are either technologically infeasible, or much less effective than EPA at first thought, so that compliance with emissions reductions standards predicated on those technologies could only be achieved at much greater cost than estimated by EPA, so costly that their adoption would force an unacceptably large number of firms in the industry into bankruptcy. ${ }^{41}$

As discussed above, technology-based standards apply to general categories of sources of regulated pollutants. Examples of regulatory targets under such a system include things such as nitrous oxide emissions from fossilfuel burning industrial boilers and electric utility generating units, volatile 
organic compounds emissions from the industrial coating or painting of metals and other surfaces, and organic pollutant discharges from pulp and paper mills. That is to say that the "sources" of pollution that are actually targeted by a technology-based command and control system are the exhausts or wastestreams from particular sorts of industrial production processes. Because these production processes are common to industries or industry sectors, bargaining over initial standard setting takes place between EPA and the industrial categories that it seeks to regulate.

The end result of this bargaining game is not, however, regulation of a particular firm. Technology-based standards are not actually binding on individual firms until they are implemented by state regulators, who write those standards into source-specific permits under the Clean Water Act, and into SIP's (and, more recently, source-specific permits) under the Clean Air Act. ${ }^{42}$ At this stage, firms have an incentive again to argue against the application of the general standard to their particular facility. As mentioned above, the courts held early on in the history of both the Clean Air Act and Clean Water Act that uniform technology-based standards are precisely that, and that neither EPA nor state regulators are to consider the particular costs and benefits from having one firm versus another comply with the uniform standards. There is, however, considerable evidence which suggests that firms actively contest the terms of source-specific permits, as well as the enforcement of those permits against them. In one EPA region, for example, 37 per cent of initial Clean Water Act permits were contested, with over half the challenges resulting in permit modifications that went in favor of the polluting firm. ${ }^{43}$

Both the CAA and CWA, moreover, tend to encourage such sourcespecific contests by including specific provisions allowing source-specific variances from the otherwise uniform emissions standards. The CWA specifies that where meeting the best available technology (BAT) standard poses severe economic consequences for an individual facility, a $\S 301(\mathrm{c})$ variance can be granted. ${ }^{44}$ Although the 1970 CWA did not explicitly authorize variances from BPT standards, EPA allowed them for existing sources who are able to persuade permitting authorities that the industrial process, control technology, costs, or energy considerations applicable to a specific plant are "fundamentally different" from those used in setting the uniform limitations. 45 After the Supreme Court upheld such variances (as well as EPA's view that the mere fact a particular plant has above average costs of complying with BPT standards does not make it "fundamentally different"), ${ }^{46}$ Congress 
specifically approved this practice in amending the CWA. ${ }^{47}$ Although current academic wisdom has it that such variances are of little practical significance, ${ }^{48}$ such wisdom is based on the fact that only about 60 variance requests had been submitted to EPA headquarters as of $1985 .{ }^{49}$ Not only does the number understate the total number of variance requests submitted to states and EPA regions ${ }^{50}$, but it also fails to recognize that the availability of a potential variance will often effect the decisions made by a state permitting authority even when no formal variance request is filed.

More generally, the history of the CWA's technology-based standards was not one of successive tightening to keep up with new technology, but rather one of a series of successful efforts by particular polluters and particular industries to persuade the agency and/or Congress that their situation was atypical and justified relaxing rather than tightening the technology-based standard. ${ }^{51}$

As a legal matter, source-specific variances under the CAA are more complex than under the CWA. The EPA defines a variance under the CAA as a "temporary deferral of a final compliance date for an individual source subject to an approved regulation, or a temporary change to an approved regulation as it applies to an individual source." ${ }^{52}$ The language of the statute itself, however, allows the EPA to approve exemptions of sources from compliance with SIP's only under very limited circumstances. ${ }^{53}$ As interpreted by the Supreme Court and EPA, a source-specific variance granted by a state can only be recognized by EPA if it is submitted to EPA as revision of the state's SIP. ${ }^{54}$ EPA, moreover, has traditionally required states to produce very costly and time consuming emissions modeling data before it would approve such revisions. ${ }^{55}$ The 1990 amendments to the CAA did nothing to upset such rules, requiring the any SIP revision submitted as a revision to a RACT-based control requirement in an SIP achieve the same overall level of emissions reductions as would be achieved under the RACT standard. ${ }^{56}$ As before 1990, it seems that EPA will only approve source-specific variances if the state seeking such a variance produces costly modeling data showing that the variance will not produce a net increase in emissions. ${ }^{57}$ Since such an increase is the point of granting a variance, it is generally pointless for states to make such an attempt to get EPA to approve source-specific variances as SIP revisions.

Does this mean that firms facing very high costs of complying with the CAA's technology-based standards (or for whom compliance is simply not technically feasible) have given up and simply incurred the costs or closed 
down? Perhaps some have, but local air quality regulators and EPA have generally found ways to get around the legal impediments to SIP revisions and succeed in granting variances. In at least one instance, EPA has approved an SIP that gives the discretion to local regulators to approve alternate compliance methods proposed by companies (so that approving such methods does not require revising the SIP). ${ }^{58}$ In California, which has thirty-four air quality districts, hearing boards in each district decide variance requests under a set of rules established by statute statute. ${ }^{59}$ Given a showing that the company requesting the variance is a "good" actor, and is attempting to minimize the pollution, such hearing boards routinely grant variances on the ground that the cost to the company of meeting a local RACT-based standard is large, or would even cause the company to shut down, while the emissions increase involved in granting the variance is relatively minor. ${ }^{60}$ Even though they would generally not meet with EPA approval if submitted as SIP revisions, ${ }^{61}$ around 1200 such variances (mostly for VOC emissions) were granted in California each year during the late 1980's and early 1990's. ${ }^{62}$ Individual case studies of the variance process would be of great interest, but are rare. Those that do exist indicate suggest that while variances are sometimes granted to firms that have made every effort to comply with the existing standard but face insuperable technological obstacles to so doing (so great that they would shut down rather than comply), in other cases they have been granted to firms that are important local employers but have made little or no effort to comply. ${ }^{63}$

Even if facility-specific compliance costs are not grounds for granting a variance, such costs can be considered at the regulatory enforcement stage. Indeed, early in the judicial interpretation of the CAA, the Supreme Court held that while assertions of technological or economic infeasibility were irrelevant in the EPA's determination of NAAQS, it was appropriate for regulators to consider them in fashioning compliance orders for noncomplying firms. ${ }^{64}$ 


\section{Alternative Models of Command and Con- trol Regulatory Standards}

\subsection{The Regulatory Contest Summarized}

The bargaining game generated by the system of technology-based standards described in the previous section has the following key features:

i) Because emissions standards apply to categories of point sources of pollution that are typically within the same industry group or sub-group, bargaining over such standards involves EPA bargaining with both individual firms within such categories and trade groups that represent such industries;

ii) Entitlements in bargaining over emissions standards are blurry, uncertain and categorical, versus individual. Thus EPA is allowed to consider, and firms to argue, that the economic costs and dislocations to local economies will be high, and the corresponding reduction in pollution low, but only relative to the regulatory category as whole. Typical of the issues that arise in this persuasion game are: What proportion of firms in the industry will go out of business if they are required to meet the proposed standards? How much will firm costs increase, on average across the industry or source category, if the proposed standards are implemented? What will be the average emission reduction achieved by firms if they install the technology that provides the basis for the standard? Are better alternative approaches available, and if so, at what cost?

iii) Industry or source-wide standards are not actually effective until implemented and enforced by state and local regulators. At the implementation and enforcement stage, bargaining is primarily between state and local regulators and individual firms. While the law does not generally allow regulators to take the uniform, categorical standards and craft them into particularized requirements that are designed to reflect the costs and benefits from the standard at a particular plant or facility, state and local regulators are sensitive to such costs and benefits, and will exercise their discretion by allowing varying amounts of time for firms to comply with the uniform standards and, even more importantly, by generally eschewing rigid enforcement in favor of negotiation toward compliance.

Under uniform, categorical technology-based emissions standards, such bargaining effects not only the emissions standard that is set for a given industrial category, but the categorization scheme. Although facilities per-

Johnston, Tradable Pollution Permits 
forming a particular industrial operation may seem very similar to a layperson, they often are quite different from a technical or engineering point of view, and these differences can cause large differences in their actual cost of achieving a given emissions reduction standard. Two metal finishing shops, for example, may both anodize aluminum for surface coating. Wastewater from such anodizing shops contains aluminum and sulfate, and both can be precipitated out by using a lime slurry. However, if other metals are present in the wastewater, introduced, for example, in electrolytic coloring baths, then there will often be a trade-off between precipitating out these metals and aluminum: to get the other metals out, less aluminum can be eliminated. ${ }^{65}$ Thus if one of the metal finishing shops is coloring its anodized aluminum while the other is not, then the shop doing the coloring will have a higher cost of meeting any given aluminum effluent reduction requirement. Variations in plant size and operating levels also generate variations in compliance costs. There are a number of different ways for plants to remove particulate air pollutants from their airborne waste streams, including mechanical collectors, fabric filters, wet scrubbers and electrostatic precipitators. ${ }^{66}$ The efficiency of these various methods of removing particulates depends upon the level at which they are operated (the flow of particulates), with efficiency falling off for many types of equipment when operations fall above or below design capacity. ${ }^{67}$ Somewhat more simply, a coal burning electric utility generating plants cost of reducing its sulphur dioxide emissions depends upon its location relative to sources of low sulphur coal. ${ }^{68}$ Plants that have cheap access to low sulphur coal can reduce sulphur dioxide emissions more cheaply than can plants for whom such coal is more expensive and for whom scrubbers are actually cost-minimizing.

In virtually any industry, production facilities vary so much in age, design, operation rates, raw material composition and transportation and other costs that few if any have precisely the same cost of achieving a given level of reduction in pollution. For this reason, when EPA bargains with industry over uniform, categorical emission standards, it typically faces arguments to the effect that certain kinds of plants are in fact so dissimilar that they should be categorized differently. More precisely, because any given pollution reduction technology achieves different levels of pollution reduction in different plants, it will often (perhaps usually) be true that lots of plants will not be able to achieve the average level of emissions reduction that EPA finds from its sample of facilities employing the technology. For these plants, the actual cost of achieving the targeted emissions reduction will be much 
higher than for the average, sampled facility. Companies owning such high cost plants have every incentive to argue to EPA that their plants should actually be recategorized in a different (regulatory, if not product market) industry. As indicated by the large number of categories and sub-categories created by EPA under statutes such as the Clean Air and Clean Water Acts, those arguments often meet with success.

iii) However the categories are ultimately drawn, categorical standards are not actually effective until implemented and enforced in facility-specific permits written by state and local regulators. At the implementation and enforcement stage, bargaining is primarily between state and local regulators and individual firms. While the law does not generally allow regulators to take the uniform, categorical standards and craft them into particularized requirements that are designed to reflect the costs and benefits from the standard at a particular plant or facility, state and local regulators are sensitive to such costs and benefits, and will exercise their discretion by allowing varying amounts of time for firms to comply with the uniform standards and, even more importantly, by generally eschewing rigid enforcement in favor of negotiation toward compliance.

\subsection{Formalizing Alternative Versions of Command and Control}

With so many stages - beginning with lobbying over the initial promulgation and finalization of a regulation, continuing through challenges to the regulation in court, and ending with bargaining over the actual implementation and enforcement of a regulation - it is perhaps unsurprising that environmental economists have failed to develop formal models of how command and control regulation actually works. That is, they have been quick to argue that because environmental regulators lack the information to craft emissions standards accurately reflecting facility-specific costs and benefits, incentive-based alternatives to command and control such as TPP regimes are likely to be more efficient than command and control. ${ }^{69}$ But they have not attempted a formal specification of command and control that would allow more realistic comparison with outcomes under such incentive-based regimes. ${ }^{70}$

In the absence of any existing, canonical formal specification, I consider instead two contrasting versions of command and control: Idealized and Bar-

Johnston, Tradable Pollution Permits 
gained.

\subsubsection{Idealized Command and Control}

Under what I call Idealized command and control, the regulation requires all firms to abate their pollution from a status quo of one unit down a level $x \in(0,1)$. Hence the cost to the ith firm of complying with such a pollution reduction standard is given by $(1-x) c_{i}$. Under Idealized command and control, the regulatory standard is costlessly and perfectly enforced, and with such a high sanction for noncompliance, $F$, that every firm finds it cheaper to comply than to incur the sanction.

\subsubsection{Bargained Command and Control}

To formalize Bargained command and control, I adapt a simplified version of a model developed by Montero. ${ }^{71}$ In this model, there is a continuum of firms, of mass equal to 1, each of which emits one unit of a uniform pollutant. Firms vary according to their (constant) marginal cost of abating this one unit of pollution, and the distribution of firm (constant marginal) abatement cost $c$ is given by the continuous density function $g(c)$ defined on $[\underline{c}, \bar{c}]$, with cumulative distribution function $G(c)$. Given its knowledge of this distribution function, the regulator can infer the aggregate industry abatement cost curve $C(q)$ for $0 \leq q \leq 1 .^{72}$

Under bargained command and control, firms do not automatically comply with a regulation requiring pollution to be reduced in the amount $(1-x)$. Rather, assuming still that the fine for noncompliance, $F$, is so high that firms would never simply fail to comply and acquiesce in paying the fine, they choose instead between complying and fighting the regulation. That is, in bargained command and control, there is a chance that by fighting the regulation - playing the regulatory game - the firm will either get its plant recategorized into a different (and less stringently regulated) category, or else obtain a variance or some other plant-specific relief. Now the regulatory game obviously has several stages, and a complete analysis of outcomes in that game can only be done within the context of a sequential bargaining model. ${ }^{73}$ There are, however, a number of very general features of equilibria in such games that can be seen even within a very simple, reduced form model.

The following is a fairly general version of such a model. To simplify the

Johnston, Tradable Pollution Permits 
regulatory game, I assume that it is a complete information game played by a risk neutral regulator and firm, and I restrict attention to subgame perfect equilibria. In the regulatory game, the firm chooses whether to comply or contest the regulation. If it contests the regulation, then the firm and the government simultaneously choose how much to invest in the contest - their effort levels - and these effort levels are the sole determinant of the outcome of the contest. (Thus the restriction to subgame perfect equilibria means that a firm will engage in the regulatory contest only if its expected total cost from the contest is less than the cost of compliance.) To sharpen the basic result, I assume that if the firm wins the regulatory game, it is not regulated at all. Let the probability that the firm wins the regulatory contest (and is not regulated) be given by $q\left(e_{i}, e_{g}\right)$ where $e_{i}$ is the firm' s effort level in the conflict and $e_{g}$ is the government' s effort level in the conflict. Assume that effort has unit cost, and assume further that $q_{1}<0, q_{11}>0, q_{2}<0, q_{22}>0$; that is, both the firm and government have declining marginal productivity of effort. I assume also that the regulatory contest function is perfectly symmetric, in that $q\left(e_{i}, e_{g}\right)=1-q\left(e_{g}, e_{i}\right){ }^{74}$

Now taking the government's effort level as fixed (the Cournot assumption), a firm with compliance $\operatorname{cost} c_{i}$ chooses its effort level $e_{i}$ to solve:

$$
\min _{e_{i}} q\left(e_{i}, e_{g}\right) e_{i}+\left[1-q\left(e_{i}, e_{g}\right)\right]\left(e_{i}+c_{i}+F\right)
$$

The first order condition to this problem (which exists, by the assumptions made above), $e_{i}$ is defined by:

$$
q_{1}\left(e_{i *}, e_{g}\right)=\frac{1}{c_{i}+F}
$$

From equation (2), it follows immediately that (provided the firm s reservation profit constraint is satisfied) the higher is $c_{i}$, the firm s marginal cost of compliance, the higher will be optimal effort level in the regulatory game, $e_{i} *$.

Now consider the government regulator. Suppose that the regulator perceives a benefit $B(1-x)$ from eliminating an amount $x$ of pollution, with $d B / d(1-x)>0$, so that $d B / d x<0 .{ }^{75}$ That is, the regulator' s benefit increases as the required level of pollution reduction increases (the permitted level of pollution falls.)

The government's objective in the regulatory game is to choose $e_{g}$ so as

Johnston, Tradable Pollution Permits 
to:

$$
\left.\max _{e_{g}}\left[1-q\left(e_{i *}, e_{g}\right)\right]\left(B(1-x)-e_{g}\right)\right)-q\left(e_{i *}, e_{g}\right) e_{g}
$$

The first order condition defining the interior solution $e_{g *}$ to this problem is given by:

$$
q_{2}\left(e_{i}, e_{g *}\right)=\frac{-1}{B(1-x)} .
$$

As $q_{22}>0$ by assumption, $\partial e_{g *} / \partial B>0$; that is, the government' $\mathrm{s}$ optimal effort level increases with its benefit.

For a given pollution standard $x_{s}$, let the net expected payoffs to the government regulator and to the firm (net, that is, of effort cost) from the regulatory game be denoted respectively by:

$$
\begin{aligned}
& R_{g}\left(x_{s}\right)=\left[1-q\left(e_{i *}, e_{g *}\right)\right] B\left(1-x_{s}\right)-e_{g *}, \quad \text { and } \\
& \left.R_{i}\left(x_{s}\right)=\left[1-q\left(e_{i *}, e_{g *}\right)\right]\left(c_{i}\left(1-x_{s}\right)\right)+F\right)+e_{i *}
\end{aligned}
$$

Several observations may now be made regarding the regulatory contest.

1. As a general matter, as in any complete information game of conflict, the firm and the government are both better off negotiating and settling rather than actually fighting the regulatory contest. The reason is that by settling, they both save the expenditure on contest effort that they would have made were the contest not averted. From the government's point of view, the continuity of the benefit function $B(1-x)$ means that there is always some level of negotiated pollution reduction, $x_{i}$ such that $B\left(1-x_{i}\right)=$ $R_{g}\left(x_{s}\right)$. The analogous result holds for the firm. Provided that $R_{g}\left(x_{s}\right)<$ $R_{i}\left(x_{s}\right)$, that is, provided that the government' s net expected benefit from the regulatory game is less than the firm' $\mathrm{s}$ expected total cost from the regulatory game, there will always be a negotiated firm-specific pollution reduction $x_{i}$ that makes both the firm and the government better off relative to their expected payoffs from a regulatory contest.

2. However, unlike private litigation - where the defendant' $\mathrm{s}$ loss at trial equals the plaintiff' s gain - the stakes in the regulatory contest are generally unequal. For this reason, we cannot be sure unambiguously that there is room for settlement in the regulatory contest. Indeed, there are two general cases.

i) When the government has much more at stake in the contest than does the firm, (the regulatory benefit of winning, $B(1-x)$, is much greater 
than the private cost of losing, $\left.c_{i}+F\right)$, then there will be no agreed level of compliance that makes both parties better off than they are (in expected value terms) contesting over the standard $x_{s}$. If the contest ensues, then by the first order conditions (2) and (4) above, the government will expend much more effort than will the firm, leading to a low probability of firm success $q$. Thus when the firm has a low compliance cost $c_{i}$, it will probably lose the regulatory contest, and will probably be better off simply complying than contesting the regulation. Quite differently, a low fine, $F$, can be seen to have a somewhat paradoxical effect: ceterus paribus, a low fine induces a lower level of firm effort in the regulatory contest, increasing the expected regulatory payoff from such a contest. By keeping fines low, the government lessens firm incentives to fight regulation.

ii) As the firm's cost of compliance $c_{i}$ increases (holding $B(1-x)$ constant), it will eventually be the case that $R_{g}\left(x_{s}\right)<R_{i}\left(x_{s}\right)$, so that a negotiated, firm-specific pollution reduction will typically make both parties better off than they would be (in expected value terms) if they proceed with the contest. Moreover, because of my symmetry assumption on $q()$ and on effort costs, when $c_{i}+F>>B(1-x)$, it will also be the case that $e_{g *}<<e_{i *}$ and that $\partial e_{g *} / \partial e_{i *}<0 .{ }^{76}$ When the firm has a lot more at stake than the government, it puts a lot more effort into the regulatory contest, and when this is true of relative effort levels, the government's optimal effort level is actually falling in the firm's optimal effort level. ${ }^{77}$

3. Another way to put the last fact is that the higher is the firm's compliance cost, the bigger is the firm's expected cost in the regulatory contest - $\left(R_{i}\left(x_{s}\right)\right.$ - but also the lower is the government's expected payoff from the contest $-R_{g}\left(x_{s}\right)$. While the precise bargaining solution varies, of course, with the relative bargaining power of the firm and the regulator, it is likely that as the firm's compliance cost increases, its impact in driving down the government's expected payoff from the contest will be the dominant effect on settlement. ${ }^{78}$ If this is so, then the negotiated firm-specific pollution reduction that the government will demand in lieu of fighting the regulatory contest will be lower, the higher is the firm's compliance cost.

4. It follows directly that for sufficiently high firm compliance $\operatorname{cost} c_{i}$, the government's expected return from the regulatory contest will be negative for all $e_{g *}\left(c_{i}\right)>0$, and so the government no longer has a credible threat to regulate, and firms with such high compliance cost are not required to reduce their pollution. ${ }^{79}$

5. The rational regulator's expected benefit - either from the regulatory 
contest or via a regulatory settlement - does not necessarily increase monotonically with $\left(1-x_{s}\right)$, the pollution reduction standard. As can be seen by totally differentiating (3) with respect to $x$, the indirect effect of increasing $\left(1-x_{s}\right)$ in inducing more firm effort in the regulatory contest can actually cause the government's expected payoff to begin to fall with such increases.

6. It may seem unreasonable to suppose that the regulator and firm engage in the bargaining game with complete information about each other's payoffs (that is, with the firm knowing $B(1-x)$ and the regulator knowing $c_{i}$ ). While a full analysis of the incomplete information case is beyond the scope of the present chapter, the usual effect of incomplete information about payoffs in making settlement less likely may not be a severe problem in the regulatory contest context. For instance, if the regulator knows only the average firm compliance cost $\mu=E\left[c_{i}\right]$, then provided that fighting the contest is credible for the average firm and for the regulator given the average firm's effort investment, it might seem that even firms with above average costs (and optimal contest effort levels) may end up engaging in the contest, because they cannot find a way to credibly persuade the regulator that their investment will be so high that the regulator is better off settling for a lower, firm-specific pollution reduction. But in such a case, firms actually have an incentive to reveal information to the regulator, in that both will be better off if the conflict is avoided. Of course, incentives are not perfectly aligned, since firms have an incentive to overstate their costs so as to get as small a bargained, firm-specific pollution reduction as possible. Still, the shared interest in avoiding a costly regulatory conflict does create an incentive to share at least some information.

This relatively foregoing formal analysis of bargained command and control may be summarized in the following proposition:

Proposition 1 For a given formal regulatory pollution standard $x_{s}$, when firms can contest regulation, and both the firm and the regulator optimally choose efforts levels in the contest with full information regarding each other' $s$ payoffs and settlement is possible, the likely regulatory outcome is one in which: a) firms with compliance cost $c_{i}$ below a cutoff value $c_{l}$ comply and do not contest the regulation; b) firms with compliance costs $c_{i}$ such that $c_{l} \leq c_{i} \leq c_{h}$ settle with the regulator for a firm-specific pollution level $x_{i}>x_{s}$; and, c) firms with compliance costs $c_{i}>c_{h}$ are not regulated and do not reduce pollution, where $c_{h}$ is defined by $R_{g}\left(x_{s} ; c_{h}\right)=0$.

Johnston, Tradable Pollution Permits 


\section{TPP Programs as both a Result, and In- creasingly Important Solution to the Patholo- gies of Categorical,Technology Based Fed- eral Environmental Standards}

\subsection{Why are there any TPP Programs?}

That TPP programs were not included in first generation American environmental regulation is hardly surprising. Before creating markets in entitlements to pollute, those entitlements had to be created in the first place. Given that the status quo was a right to pollute and that reductions in pollution typically involved large sunk investments (in secondary wastewater treatment, end-of-stack scrubbers, and similar equipment), new entitlements were worked out only through a long and costly negotiation process involving literally thousands of lawsuits. To the extent that new entitlements were actually negotiated, they took the form of the technology-based standards that I have described in some detail above. A regulatory regime based upon such technology-based standards is inherently inconsistent with a TPP regime. TPP regimes, after all, operate by setting aggregate pollution caps for a particular pollutant, allocating that aggregate amount of pollution across identified sources of such pollutant, and then allowing firms to comply either by reducing the pollution sources they own down to the level of their allocation, or by buying allocations from other firms. As even their most committed advocates concede, the effectiveness of a TPP regime, as with any regulatory regime, hinges upon effective enforcement enforcement which makes it cheaper for firms to comply either by buying permits or by reducing pollution than to fail to comply. Because TPP regimes are output-oriented they do not regulate how firms get into compliance, but whether they are in compliance

- the effectiveness of TPP regimes hinges upon accurate monitoring of firms emissions and permit purchases, and upon the assessment of an adequately severe penalty upon those firms found not to be in compliance.

The existing technology-based command and control system does not possess the preconditions for successful pollution permit trading. The first problem is that technology-based standards do not, by their very definition, require source specific monitoring. Hence cap and trade regimes that are simply engrafted upon existing technology-based regulations (such as the Re-

Johnston, Tradable Pollution Permits 
gional Clean Air Incentives Market - RECLAIM - set up for the L.A. basin) require firms to self-report their emissions. Given that regulators have limited budgets, and can only audit and (imperfectly) verify a small fraction of the emissions self-reports, there is an obvious incentive for firms to underreport their actual emissions. Critics of existing cap and trade schemes such as RECLAIM that rely upon self-reporting ${ }^{80}$ argue that such underreporting is pervasive. ${ }^{81}$

There is another much more basic obstacle to engrafting emissions trading upon the existing technology-based regulatory framework. Even with limited enforcement resources, the existing command and control regulatory system has generally been effective in creating an incentive for the largest and most visible firms to come into compliance with existing technology-based standards. As argued above, however, even if most firms are in compliance with such standards, there is little if any incentive for firms to go beyond compliance when operating in such a regulatory environment. Hence while there may well be firms who are not in compliance and who might be willing buyers of pollution permits there will not be many firms who have gone so far beyond existing regulatory requirements that they would have unused pollution permits that they might sell. That is, if firms are minimizing their compliance costs under an existing technology-based regulatory regime that they expect to be relatively stable in the future, then the aggregate level of emissions will be slightly above what the technology-based standard would imply (because some firms are out of compliance in equilibrium). A cap and trade regime which sets the aggregate cap at or below the emissions level that should be obtaining under the status quo regulatory regime will therefore generate lots of firms that would like to buy because they were not really in compliance, and hence need to buy permits but very few if any who are willing to sell. Simple economics might seem to teach that lots of buyers versus only a few sellers means that the price of pollution permits will be very high. But this is simplistic rather than simple economics. When transaction costs are high, markets may fail to exist in the first place. Moreover, unlike most goods, the supply of pollution permits is fixed (by regulators). With a fixed supply that falls far short of the number of permits demanded, market equilibrium will involve lots of willing buyers who simply were unable to find a permit to buy.

This story helps explain the relative failure of EPA's oldest experiment with TPP's, the requirement under the CAA that new major air pollution sources in nonattainment areas offset new source emissions with decreases 
from an existing source or sources. ${ }^{82}$ There were thousands of offsets during the first ten years of this program (1977-1986), but the vast majority of these were "internal" offsets - offsets obtained because a firm that constructed a new source of air pollution found a way to reduce pollution at an existing source that it owned. There were few if any external offsets, exchanges where the firm building a new source contracted for a reduction of emissions at some other firm. ${ }^{83}$ The failure to observe very many offset trades was due to a number of factors. Notably, without a scheme that first gives firms credit for "extra" emissions reductions relative to status quo regulatory requirements as by allowing them to "bank" such excess emissions reductions offset trades across firms are possible only when there is a lucky coincidence of one firm reducing emissions at the same time another is building a new source. Given that few states had implemented banking, and that the status of banked emissions was at best uncertain, the transactions costs obstacles to the formation of offset markets were even higher than dictated by the incentives created by the status quo command and control regulatory regime. ${ }^{84}$

The difficulty of engrafting trading schemes on existing command and control regimes also explains why TPP program have sometimes worked. There are two examples of relatively successful TPP regimes in federal environmental law and regulation the Title IV Acid Rain trading scheme, and EPA's lead phasedown program. These programs are discussed in some considerable detail in other chapters. ${ }^{85}$ For present purposes, what is most notable about each of these programs is that they did not simply involve engrafting a tradable permits regime on an existing technology-based system. Initiated in 1982, EPA's lead phasedown program allowed gasoline refiners to trade lead content allowances under an overall cap on lead gasoline additives that declined to zero over the life of the program. ${ }^{86}$ The program allowed unused allowances to be banked for up to three years, and succeeded in encouraging an active market in lead allowances. While there were a number of factors accounting for the programs success as a trading regime such as its simplicity, relatively small number of participants and the certainty that banked allowances could indeed be sold ${ }^{87}$ perhaps the key factor in explaining the programs success was that the overall goal of the program the steady decline in and eventual elimination of lead additives was clear. Given that this goal was relatively inexpensive for some firms to meet, while completely infeasible for others (who went out of business), perhaps the clearest lesson of the lead phasedown program is that by lowering the cost of achieving an 
ambitious overall emissions reduction goal, trading can make such a goal politically feasible when it otherwise would not be.

A similar but more extensive illustration of this phenomenon is provided by the Acid Rain program. Enacted as Title IV of the 1990 amendments to the CAA, ${ }^{88}$ set up a stand alone sulfur dioxide cap and trade program applying (over two phases) to some 800 electricity generating units. That program sought to achieve a steady reduction in aggregate, nationwide sulfur dioxide emissions. The accumulating evidence indicates not only that the program has succeeded, but that it has succeeded both because it allows firms the flexibility to find the lowest cost way of reducing emissions (installing scrubbers, buying low sulfur eastern or western coal), but also because some high cost of compliance firms have complied by buying emissions permits from low compliance cost firms. ${ }^{89}$ That the Title IV program happened at all was due to perceived breakdown of technology-based regulation as applied to the electric utility generating industry. Under the differential treatment of "old" versus "new" sources which is typical of such regimes, the CAA's acid rain regulations had focused on new power plants while grandfathering older plants, producing a situation where by 1985, 83 per cent of power plant sulfur dioxide emissions came from generating units that did not meet that 1971 standards required of new sources. ${ }^{90}$ Environmentalists and political representatives from eastern states perceived as bearing the costs of acid rain wanted faster and greater reductions in aggregate emissions, and in particular wanted emissions reductions at the dirtiest facilities. Given the cost to such facilities of meeting such tough emissions targets, the cap and trade system emerged as a compromise: the least cost method of achieving overall emissions standards that were significantly tougher than under the existing law. ${ }^{91}$ The the Title IV program did not represent a situation where tradable permits were engrafted on an existing technology-based system, but rather a movement from such a system to a relatively pure TPP system in which firms were given source-specific permits. "Given" is indeed a misnomer, in that the statutory allocation of initial Title IV permits reflected a costly legislative lobbying game. ${ }^{92}$

\subsection{How TPPs Change the Regulatory Bargaining Game}

The previous sections discussion of existing TPP programs in American federal environmental law suggests that while attempts to engraft TPP regimes

on existing technology-standards-based systems have often failed for lack of

Johnston, Tradable Pollution Permits 
support from industry and others, there are circumstances when such programs can succeed. The case studies discussed above indeed suggest that TPP regimes may make it much easier for regulators to impose tougher emissions standards, relative to technology-based standards. This section formalizes this intuition. I show that unlike proposals to base emissions standards on particularized, source-specific, cost-benefit determinations which often threaten firms with big changes in equilibrium compliance costs that have big consequences for their relative profitability and competitiveness most and sometimes even all firms in an industry sector can be better off under TPP regime than they would be if regulators attempted to achieve the same level of aggregate emissions using technology-based standards.

Underlying this demonstration is a basic intuition that trading itself may significantly alter the dynamics of the regulatory bargaining game. The reason is that whenever firms differ in their costs of meeting a given regulatory standard by which I mean an emissions target trading will unambiguously lower the regulatory compliance costs of those firms with the highest such costs, firms that spend the most in opposing tougher command and control standards.

\subsubsection{Firm Costs under a TPP Regime of Varying Ambition: For- mal Analysis}

To see these points formally, consider again the formal model developed above. Consider first a tradeable permits regime under which each firm is given a permit to emit $x$ amount of pollution. Under such a regime, firms can comply either by incurring the marginal cost $c$ of compliance, or by buying permits at market price $p$. I shall assume that tradable permits regime is one in which firms are required to install an emissions monitoring system that perfectly informs the regulator as to their emissions level and that regulators have perfect knowledge of each firms permit buy and sell history. Hence under the tradeable permits regime, the regulator costlessly obtains perfect information as to whether each firm is in compliance. As under idealized regulation, firms that are not in compliance are made to pay a very large fine $F$.

The question of interest is how firms equilibrium costs differ under the command and control versus the tradable permits regimes. To answer this question, we must solve for the equilibrium under a tradeable permits regime. And as discussed above, equilibrium cost distribution under a tradeable per-

Johnston, Tradable Pollution Permits 
mits regime depends upon the market equilibrium, upon which firms will buy permits and which will sell. To solve for this equilibrium, I simplify by considering a closed system: one in which only the regulated firms may buy or sell permits. ${ }^{93}$ Let $p$ be the equilibrium price of permits. Consider first those firms with $c<p$. Because for such firms $c<p$, they will always be better off abating fully (the entire 1 unit of pollution) and selling the excess allowance than abating just down to the allowed level (that is, $c(1-x)>c-x p$ when $p>c$.) Such firms are better off fully abating and selling excess permits than than not complying provided that $c-x p<F$, which must be true for a sufficiently high fine.

Now consider firms with $c \geq p$. It is cheaper for such firms to buy permits than to abate and sell (that is, for these firms, $c-x p>c(1-x)$.) Such firms are better off buying permits than failing to comply provided that $(1-x) p<F$, which once again must hold for sufficiently large fine $F$.

The market price $p$ is determined by the market equilibrium condition that supply equals demand:

$$
\begin{gathered}
x \int_{\underline{c}}^{p} d G=(1-x) \int_{p}^{\bar{c}} d G, \text { or } \\
x G(p)=(1-x)(G(\bar{c})-G(p)), \text { which becomes } \\
(1-x)=G(p), \text { so that } \\
p(x)=G^{-1}(1-x) .
\end{gathered}
$$

Using expression (5) for $p(x)$, we have that:

$$
\begin{gathered}
p^{\prime}(x)=\frac{-1}{g(1-x)}<0 \quad \text { and } \\
d / d x[x p(x)]=p(x)-\frac{x}{g(1-x)}=G^{-1}(1-x)-x g(1-x)>0 \Leftrightarrow \\
\frac{G^{-1}(1-x)}{x g(1-x)}=\eta_{d}>1,
\end{gathered}
$$

where $\eta_{d}$ is the elasticity of demand for permits.

Johnston, Tradable Pollution Permits 
Expressions (8) and (9) have a number of implications for how changes in the stringency of the cap and trade program affect buyers versus sellers of permits. Most directly, by (8) a change in $x$, the initial number of permits given to each polluter, obviously changes the identity of the marginal buyer and seller of permits. For non-marginal buyers and sellers, we have the following:

Result 1

As the number of permits given to polluters, $x$, increases - as the cap and trade program becomes relatively less ambitious in its pollution reduction goal - the price of permits falls and so the net cost of the cap and trade program to high compliance cost permit buyers falls;

\section{Result 2}

For permit sellers, an increase in the number of permits initially given to each polluter may increase or reduce their net expected cost under the permit program. Only if the elasticity of permit demand $\eta_{d}>1$ will an increase in the number of permits actually reduce the net cost of the cap and trade program to permit sellers. That is, if demand is elastic, then an increase in the number of permits for sale has only a small effect in depressing the permit price, and so net seller revenue increases for non-marginal sellers.

\subsubsection{Comparison with Command and Control(CAC)}

Letting the CAC pollution standard be denoted simply by $x$ (rather than $x_{s}$ as earlier), the two stylized versions of command and control developed earlier generate the following equilibrium outcomes:

Under idealized CAC, all firms reduce by one unit, at cost $c_{i}$;

Under Bargained CAC, firms with $\operatorname{cost} c_{i}<c_{l}$ comply by reducing pollution down to the standard level $x_{s}$, while those with $c_{i}$ such that $c_{l}<c_{i} \leq c_{h}$ reduce pollution down to a negotiated level $x_{i}>x$, and those with $c_{i}>c_{h}$ do not reduce at all.

i) Under Idealized CAC, firms that would be buyers in a cap and trade program would have costs equal to $c(1-x)$ which must exceed their actual net cost under cap and trade, given by $p(1-x)$, because these firms are such that $c>p$. Likewise, firms with $c \leq p$ sell permits under cap and trade have a net cost under that regime of $c-x p$ but would have a net cost of $c(1-x)$ under the command and control regime, but for $c \leq p, c-x p \leq c-x c=c(1-x)$ and so have lower net costs under cap and trade than under command and control.

Johnston, Tradable Pollution Permits 
ii) Under bargained CAC, only firms with $c_{i} \leq c_{h}$ actually incur compliance costs and reduce pollution. Moreover, under bargained command and control, firms with $c_{i}$ such that $c_{l} \leq c_{i} \leq c_{h}$ reduce pollution not by the full amount $(1-x)$, but rather by some amount $\left(1-x_{i}\right)$ with $x_{i}>x$. Under the cap and trade regime, only firms with $c_{i}<p(x)$ actually comply by reducing pollution, but firms with $c_{i}>p$ incur costs of $(1-x) p$ to comply by buying permits. Depending upon the structure of the regulatory conflict bargaining game under command and control, it is clearly possible that the negotiated firm-specific reductions $x_{i}$ and the threshold for no-reduction $c_{h}$ are such that the majority of firms would actually have higher costs under the cap and trade regime than they do in the status quo bargained command and control regime. Especially when firm costs increase more rapidly with a toughening emissions standard (decreasing $x_{s}$ ), than do regulatory benefits, the actual bargained command and control regime may be one in which fewer firms incur compliance costs than would incur such costs under the (perfectly enforced) TPP regime. If something like bargained command and control is the status quo against which the TPP regime is compared, then the majority of firms might well oppose a move to TPP.

\section{A Positive Implication: Explaining Title IV Allocations}

The general predictions of my model are confirmed by the pattern of Congressional allocations of sulfur dioxide pollution allowances under Title IV of the 1990 CAA. As observed earlier, the sulfur dioxide allowance trading program under Title IV of the amended CAA is the most well known, and most successful TPP program to date. One of the great contributions of Ellerman et. al. ${ }^{94}$ is their detailed explication of the complex Congressional bargaining process that culminated in the passage of Title IV. Congressional bargaining focused on the number of allowances that different coal-fired generating units would be given. That is, Title IV not only set an aggregate emissions reduction goal, but itself set the number of allowances both for Phase I, which applied beginning in 1996 to 225 large, dirty generating units with sulfur dioxide emissions rates above 2.5 pounds of sulfur dioxide per million Btu, and for Phase II, which began in 2001 and applied to all generating

units with emissions rates above 1.2 and capacity above 75 megawatts (as of

Johnston, Tradable Pollution Permits 
1985). ${ }^{95}$ As Ellerman et. al. show, Congressional allocation of both Phase I and Phase II allowances departed significantly from the basic apolitical statutory formula for allocations (which multiplied a unit's average 1985-87 energy input by a statutory emissions rate, of 2.5 for Phase I units and 1.2 for Phase II units). Old, high emission plants in high emission states whose facilities burned local high sulfur coal used their political influence to get extra Phase I allowances. ${ }^{96}$ For Phase II, over thirty special allocation rules written into the statute generated deviations from the base allocations. ${ }^{97}$ These allocation rules effectively made the actual level of allocations received by a generating unit much more sensitive to variations among types of units than the baseline allocation formula countenanced. To the surprise of Ellerman et. al., the actual pattern was the opposite, with the oldest, dirtiest units penalized, and newer, cleaner units given extra allowances (relative to the base formula). ${ }^{98}$ Ellerman et. al., come up with decidedly non-economic, ad hoc explanations for this pattern, attributing it to a Congressional sense of fairness - that it would be unfair to require even more of plants that already relatively clean - or, conversely, to the desire of Congressional representatives from clean coal (or natural) gas burning western states to get revenge for the costs the dirty coal state representatives had imposed on clean states in prior versions of the CAA. ${ }^{99}$

By a very direct extension, ${ }^{100}$ my model provides a relatively simple economic explanation for the pattern of Phase II allowances under Title IV: differing marginal control costs under the existing, pre-Title IV status quo regulatory regime. Under the pre-1990 regime, the oldest, dirtiest plants had been grandfathered out of federal emission rate standards, and were subject only to widely varying and often lax state regulation under state implementation plans. New plants were, conversely, subject to tough federal emission rate standards, plus the politically motivated, redundant scrubber requirement that was the subject of clean state ire. Under the rather bizarre pre-1990 status quo command and control regime, ${ }^{101}$ the newest, cleanest plants were subject to the toughest emission rate regulations. Unsurprisingly, as found by Ellerman et. al., because they had done little if anything to reduce their sulfur dioxide emissions, marginal sulfur dioxide control costs were lowest in old, dirty plants ${ }^{102}$, whereas they were higher in the cleaner, newer plants. This status quo regime is precisely what I have called the regime of bargained command and control, a regime under which the dirtiest plants have such large costs of meeting the target emissions reductions that they actually end up being unregulated. Newer, more efficient plants are reg- 
ulated and required to achieve substantial reductions in emission rates. Such a regulatory regime generates a bargained equilibrium in which the cleanest plants have already been forced to reduce their emissions, and hence have higher marginal costs of further reductions than to do the dirtiest plants, who have been left unregulated. My model explains the otherwise paradoxical pattern of Title IV Phase II allowances as reflecting opposition to a simple Title IV regime by owners of clean plants - those who relative to an equal baseline would have the lowest marginal control costs, but whose actual, CAC-induced marginal control costs are quite high. That clean units demanded special additional allowances before their representatives would sign on to Title IV reflects that fact that they were the ones being most stringently regulated under the status quo CAC regime.

\section{A Normative Implication: The Ideal Ver- sus the Real in Air Pollution Regulation}

Another contribution of the analysis here is to show the significance of taking the correct baseline in evaluating a move from a CAC regime to a TPP regime. The significance of baselines is well-illustrated by the recent debate over the Bush Administration's Clear Skies inititative. According to the Administration, Clear Skies generates "dramatic" reductions in power plant emissions of sulfur dioxide, nitrogen oxides and mercury. According to many prominent environmental groups, however, the plan's goal of a 70 per cent reduction in these emissions by 2018 is too little, and too late in coming. These groups argue that if existing Clean Air Act regulations were fully enforced, there would be bigger and quicker reductions in these pollutants from power plants. ${ }^{103}$ Such claims are true. But my analysis here suggests that the relevant comparison is very likely not between the Administration's proposed TPP regime and an Idealized CAC regulatory regime, for that regime clearly does not and has never existed. Rather the relevant normative question is whether the Administration's (or any other) proposed TPP regime is likely to generate lower levels of emissions than the current, real world CAC regime generates. If what I have called Bargained CAC roughly describes the current CAC status quo, then it is one in which the oldest and dirtiest facilities will not actually have to reduce their emissions by very much, if at all. Compared to such a Bargained regime, the Administration's proposals

Johnston, Tradable Pollution Permits 
tend to look far better than they do when compared with an Idealized, but nonexistent CAC regime.

\section{Notes}

${ }^{1}$ In the legal literature, the classic critique, and proposal for a move to auctioned, tradeable permits, is Bruce A. Ackerman and Richard B. Stewart, Reforming Environmental Law, 37 Stan. L. Rev. 1333 (1985).

${ }^{2}$ For a comprehensive if now dated discussion of many of the main theoretical and empirical results, see T.H. Tietenberg, Emissions Trading: An Exercise in Reforming Pollution Policy (1985); for a lucid and more recent introduction to the theory, see Charles D. Kolstad, Environmental Economics 155-177 (2000). For especially elegant recent contributions to the empirical analysis of tradable permit markets, see Juan-Pablo Montero, Testing the Efficiency of a Tradeable Permits, Testing the Efficiency of a Tradeable Permits Market (Darft, Sept. 6, 2002) and Paul Joskow, Richard Schmalensee and Elizabeth Bailey, The Market for Sulfur Dioxide Emissions, 88 Amer. Econ. Rev. 669 (1998).

${ }^{3}$ For a summary of the American experience with permit markets, see Gert Tinggaard Svendsen, Public Choice and Environmental Regulation: Tradable Permit Systems in the United States and CO2 Taxation in Europe 71-132 (1998). For a discussion of the failure to implement more TPP regimes, see Robert W. Hahn and Gordon L. Hester, Where did all the Markets Go? An Analysis of EPAs Emissions Trading Program, 6 Yale J. Reg. 109 (1989).

${ }^{4}$ See Keohane [this book]; A. Denny Ellerman et. al., Markets for Clean Air: The U.S. Acid Rain Program (2000).

${ }^{5}$ In 2002, the Bush Administration introduced its "Clear Skies" bill, a cap and trade program designed to reduce power plant emissions of sulfur dioxide, nitrogen oxides and mercury by 46 per cent by 2010 and by 70 per cent when fully implemented in 2018, The Clear Skies bill died in Senate Committee on Environment and Public Works. However, by regulation, EPA has proposed very similar cap and trade schemes for the same pollutants, see 69 Fed. Reg. 4, 566 (Jan. 30, 2004)(power plant sulfur dioxide and nitrogen oxide trading program) and 69 Fed. Reg. 12398 (March 16, 2004)(mercury cap and trade program). Regardless of the fate of these regulations, the so-called NOxSIP Call, which uses market based emissions trading to reduce NOx emissions from power plants and other large industrial sources in 22 states, has begun to be implemented. Finally, EPA has issued a policy and guidance document on how water quality trading between point and nonpoint sources may be used to meet new water quality — based effluent limits generated by the development of Total Maximum Daily Loads under the Clean Water Act. See Water Quality Trading Policy: Issuance of Final Policy, 68 Fed. Reg. 1608 (Jan. 13, 2003).

${ }^{6}$ In the environmental economics literature, even the most thorough analysis of alternative command and control regimes, such as Gloria E. Hellfand, Standards versus Standards: The Effects of Different Pollution Restrictions, 81 Amer. Econ. Rev. 622 (1991) and other work reviewed there considers only what I term Idealized command and control regimes, those that do not allow firms to contest and bargain over actual regulatory implementation, and which therefore do not approximate any real-world command

Johnston, Tradable Pollution Permits 
and control regime.

${ }^{7}$ Jason Scott Johnston, Federal Regulation and the Provision of Local Public Goods (draft, November, 2003).

${ }^{8}$ Resource Conservation and Recovery Act, 42 U.S.C. $\S \S 9601-6992 \mathrm{k}$.

${ }^{9}$ Comprehensive Environmental Response, Compensation and Liability Act of 1980, 42 U.S.C. $\S \S 9601-9675$.

${ }^{10}$ See, for example, Section 101(a)(1) of the Clean Water Act, 33 U.S.C. $§ 1251(a)(1)$ setting forth a statutory goal of eliminating the discharge of pollutants into the navigable waters by 1985 .

${ }^{11}$ For instance, in Section 301(a)(2)(A), 33 U.S.C. $\S 1311(\mathrm{a})(2)(\mathrm{A})$, the Water Pollution Control Act instructs the EPA to base effluent limitations for various categories of point sources of water pollution on the "best available technology economically achievable"otherwise known as "best practicable technology" - and then explains, in Section 304 of the Act, 33 U.S.C. $\S 1314(\mathrm{~b})(1)(\mathrm{B})$, that in determining what constitutes "best practicable technology, "the agency is to consider "the total cost of application of such technology in relation to the effluent reduction benefits to be achieved from such application, and shall also take into account the age of equipment and facilities involved, the process employed, the engineering aspects of the application of various types of control techniques...and such other factors as the Administrator deems appropriate."

${ }^{12}$ See Jason Scott Johnston, A Game-Theoretic Analysis of Alternative Institutions for Regulatory Cost-Benefit Analysis, 150 U. Pa. L. Rev. 1343, 1395-1401 (2002).

${ }^{13}$ A point made by Louis Kaplow and Steven Shavell, Property Rules versus Liability Rules, 109 Harv. L. Rev. 713, 751-752 (1996).

${ }^{14}$ On this point, see Clifford S. Russell, Achieving Air Pollution Goals in Three Different Settings, in To Breathe Freely: Risk, Consent and Air 233, 254 (Mary Gibson, ed. 1985).

${ }^{15}$ [appropriate cite to that chapter]

${ }^{16}$ See Howard Latin, Ideal versus Real Regulatory Efficiency: Implementation of Uniform Standards and "Fine-Tuning" Regulatory Reforms, 37 Stan. L. Rev. 1267, 1314 (1985).

${ }^{17}$ According to the statute, the new source standards are based on "the greatest degree of effluent reduction which the Administrator determines to be achievable through application of the best available demonstrated control technology, processes, operating methods, or other alternatives, including, where practicable, a standard permitting no discharge of pollutants. " 33 U.S.C. $\$ 1316(\mathrm{a})(1)$.

${ }^{18} 33$ U.S.C. $\S 1311(\mathrm{~b})(2)(\mathrm{E})$.

${ }^{19} 33$ U.S.C. $\S 1311(\mathrm{~b})(1)(\mathrm{A})$.

${ }^{20} 33$ U.S.C. $\S 1314(\mathrm{~b})(1)(\mathrm{B})$.

${ }^{21}$ This description is taken from P.D. Reed, Industry Effluenct Limitations Program in Dissarray as Congress Prepares for Debate on Water Act Amendments, 12 Envl L. Rptr. -- (1982).

${ }^{22}$ As the Supreme Court summarized the process, "every BPT limitation represents a conclusion by the Administrator that the costs imposed on the industry are worth the benefits in pollution reduction. "EPA v. National Crushed Stone Ass'n, 449 U.S. 64 at 76 (1980).

${ }^{23}$ This has been EPA practice for the last three decades. Compare, for instance, EPA, 
Final Development Document for Effluent Limitations Guidelines and New Source Performance Standards for the Phosphorus Derived Chemical Segment of the Phosphate Manufacturing Point Source Category § VIII (Jan. 1974), with the EPA's proposed but cancelled new water pollution regulations for the metal finishing industry, described in Jason Scott Johnston, The Promise and Limits of Voluntary Management-Based Regulatory Reform: An Analysis of EPAs Strategic Goals Program, forthcoming in Leveraging the Private Sector (Cary Coglianese and Jennifer Nash, eds., 2005).

${ }^{24}$ See 33 U.S.C. $\S \S 1314(\mathrm{~b})(1)(B) \&(4)(B)$ and EPA v. National Crushed Stone Assoc., 449 U.S. 64, 71 n.10, 76-77 \& n.16 (1980), both discussed in Howard Latin, Ideal versus Real Regulatory Efficiency, Implementation of Uniform Standards and 'Fine-Tuning' Regulatory Reforms, 37 Stan. L. Rev. 1267, 1314 (1985).

${ }^{25}$ See Latin, Ideal versus Real Regulatory Efficiency; Howard Latin, The Feasibility of Occupational Health Standards: An Essay on Legal Decisionmaking Under Uncertainty, 78 N.W.U. L. Rev. 583, 588, 600-602, 611-17 (1983).

${ }^{26}$ In EPA v. National Crushed Stone Assoc., 449 U.S. 64 (1980).

2742 U.S.C. $\S 7411(\mathrm{a})(1)$.

${ }^{28}$ See Sierra Club v. Costle, 657 F.2d 298 (D.C. Cir. 1981).

${ }^{29}$ Wisconsin Electric Power v. Reilly, 893 F.2d 901, 918-919 (7th Cir. 1990).

${ }^{30}$ Under 42 U.S.C.7411(b)(2). For an example of such subcategorization, see 44 Fed. Reg. 33,580 (1979)(varying NOX emissions standard for utility boilers based on boiler and fuel type).

${ }^{31}$ See Lignite Energy Council v. U.S. E.P.A., 198 F.3d 930, 933 (D.C. Cir. 1999)(upholding auniformflue gas treatment technology for NOX emissions from fossil fired industrial and utility boilers).

3242 U.S.C. $\S 7503(\mathrm{a})(2)$.

${ }^{33} 42$ U.S.C. $§ 7501(3)$.

${ }^{34} 42$ U.S.C. $\S 7502(\mathrm{~b})(2)$.

${ }^{35} 42$ U.S.C. $\S 7502(\mathrm{~b})(3)$.

${ }^{36}$ For illuminating discussions of the way in which EPA guidance documents regarding "reasonably available control technology" for particular source categories have in fact become uniform standards that SIP's must follow, see State of Michigan v. Thomas, 805 F.2d 176 (6th Cir. 1986); National Steel Corporation v. Gorsuch, 700 F.2d 314 (6th Cir. 1983); Navistar International Transportation Corp. v. EPA, 941 F.2d 1339 (6th Cir. 1991).

${ }^{37}$ Which applies to area sources subject to the hazardous air pollutants program under 42 U.S.C. $\S 7412(\mathrm{~d})$.

${ }^{38}$ Which applies under 42 U.SW.C. $\S 7513(\mathrm{a}(\mathrm{b})(1)(\mathrm{B})$ to sources of particulates in areas classified as "serious" for the nonattainment of the NAAQs for that pollutant.

${ }^{39} 42$ U.S.C. $\$ 7661 \mathrm{a}(\mathrm{a})$.

${ }^{40} \mathrm{~A}$ former EPA General Counsel's description of the effluent guidelines for textile mills gives a flavor of this process: "The regulation contains limitations for seven subcategories: wool scouring, wool finishing, dry processing, woven fabric finishing, knit fabric finishing, carpet mills, and stock and yarn dyeing and finishing. For each subcategory, there are limitations specified on the discharge of several pollutants ... separate limitations are set forth for 'best practicable control technology currently available,' 'best available technol-

Johnston, Tradable Pollution Permits 
ogy economically achievable,' and [new source performance standards]." Robert V. Zener, Guide to Environmental Law 90-91 (1981). For a case illustrating virtually the entire range of challenges that an industry may bring to technology-based standards, see Chemical Manufacturers Assoc. v. EPA, 870 F.2d 177 (5th Cir. 1989).

${ }^{41}$ Striking recent examples include the metal finishing industry's recent success in persuading EPA that it had far overestimated the effectiveness of its assumed technology, and so vastly underestimated the actual cost to industry of meeting proposed new effluent guidelines that compliance with those guidelines would have put forty per cent of the industy out of business, see Johnston, The Promise and Limits, supra note $\mathrm{xx}$, and the natural gas distribution industry's success in persuading EPA that the technology it had assumed would be used to reduce NOX emissions in natural gas fired internal combustion engines was technologically infeasible for certain types (lean burning, variable load) of these engines. See EPA, Interstate Ozone Transport: Response to Court Decisions on the NOX SIP Call, NOX SIP Call Technical Amendments, and Section 126 Rules, 67 Fed. Reg. 8396, 8411-8413 (Feb. 22, 2002).

${ }^{42}$ Under the CWA, for example, industry groups not only attacked EPA's standards (the effluent guidelines), but at the same time tried to persuade the courts that EPA's effluent guidelines were not binding on state permit writers. Until finally rejected by the Supreme Court in E.I. DuPont de Nemours v. Train, 430 U.S. 112, 126-136 (1977), this line of attack generated generated twenty federal court of appeals published decisions and no fewer than three Supreme Court opinions.

${ }^{43}$ Zamanky \& Zerbe, Adjudicatory Hearings as Part of the NPDES Permit Process, 9 Ecol. L. Q. 1, 13, 17 (1980); Implementation of the Federal Water Pollution Control Act: Hearings before the Subcommittee on Investigation and Review of the House Comm. on Public Works and Transportation, 94rh Cong., 2d Sess. 123 (176) (Report by the Comptroller of the United States).

${ }^{44}$ FWPCA $\S 301(\mathrm{c}), 33$ U.S.C. $\S 1311(\mathrm{c}) .$.

${ }^{45}$ See, e.g., 40 C.F.R. $\S \S 434.22$, 434.32, 436.22. In E.I DuPont Nemours v. Train, 430 U.S 112, at 128 (1977), the Court held that the structure of the CWA in fact required EPA to allow source-specific variances.

${ }^{46}$ EPA v. National Crushed Stone Association 449 U.S. 64 (1980). One commentator has summarized the Court's holding in this case as follows: "The Court held that the statute requires consideration of whether the costs of BPT are reasonable for the industry category as a whole, but contemplates, as the legislative history clearly indicates, that the uniform standards would apply to all plants in the category, regardless of their economic effect on individual plants. The BPT variance is properly limited to cases where an individual plant so differs from others in the category, in terms of the technology and cost considerations, that it would be irrational to apply the category-wide standards to that plant." P.D. Reed, Industry Effluent Limitations Program in Dissarray as Congress Prepares for Debate on Water Act Amendments, 12 Envl L. Rptr. -- (1982).

${ }^{47} 33$ U.S.C. $\S 1311(\mathrm{n})(1)$.

${ }^{48}$ See Farber, Taking Regulatory Slippage Seriously, (citing Pedersen, supra note _-).

${ }^{49}$ Pedersen, Turning the Tide on Water Quality, at 86 , fn. 81.

${ }^{50}$ The source of the widely-cited irrelevance of FDF variances, William F. Pedersen, Turning the Tide on Water Quality, 15 Ecology L. Q. 69, 85 (1988) was also careful to

Johnston, Tradable Pollution Permits 
add these qualifications, Id. at 86 n.81, which have unfortunately been ignored in the subsequent literature.

${ }^{51}$ Thus as Pedersen, Turning the Tide on Water Quality, 15 Ecol. L. Q. 69, 87 observes, by 1983, Congress had been persuaded to amend the law to relax the technology-based control requirements for certain conventional pollutants, codified at 33 U.S.C. Section 1314(a)(4), to exempt municipal sewage treatment plants from the toughest technologybased requirements, see Municipal Wastewater Treatment Construction Grant Amendments of 1981, Pub. L. No. 97-117, Section 21(b), 95 SDtat. 1623, 1632 (repealing section 301(b)(2)(B) of the CWA), and even relaxing effluent standards for two particular pulp mills that had failed to persuade EPA to grant them a variance. See Pub. L. No. 97-440, 96 Stat. 2289 (codified as amended at 33 U.S.C. Section $1311(\mathrm{~m})$, reversing the result in Crown Simpson Pulp Co. v. Costle, 642 F.2d 323, 326 (9th Cir. 1981).

${ }^{52} \mathrm{EPA}$, Requirements for Preparation, Adoption, and Submittal of Implementation Plans, 40 C.F.R. $\S 51.100(y)$.

${ }^{53}$ See the discussion in George Hays and Nadia Wetzler, Federal Recognition of Variances: A Window into the Turbulent Relationship between Science and Law under the Clean Air Act, 13 J. Envtl. L. \& Litig. 115, 127-141(1998).

${ }^{54}$ Id., see also Marc Melnick and Elizabeth Willes, Watching the Candy Store: EPA Overfiling of Local Air Pollution Variances, 20 Ecol. L. Q. 207 (1993).

${ }^{55}$ See Hays and Wetzler at 137.

5642 U.S.C. $\$ 7410(\mathrm{e})$.

${ }^{57}$ Constraints set out in Train v. Natural Resources Defense Council, 421 U.S. 60 (1975).

${ }^{58}$ Because such discretion is part of an SIP, when it is exercised to allow a company to depart from BACT, there is no change in the state's SIP and hence no need for EPA approval. For a case upholding such an SIP provision, see United States v. Ford Motor Co., 736 F.Supp. 1539 (W.D. Mo. 1990).

${ }^{59}$ See the discussion in Melnick and Willes, at 216-223.

${ }^{60}$ Id.

${ }^{61}$ For many years, the practice of the California Air Resources Board was to simply not submit variance orders to EPA as SIP revisions. See Melnick and Willes, at 227. The largest air quality district in California, the South Coast Air Quality Management District (which covers the Los Angeles basin) now operates under a rule worked out with EPA under which variances are treated as Title V permit modifications rather than SIP revisions. Hays and Wetzler, at 140-141.

${ }^{62}$ Melnick and Willes, at 223.

${ }^{63}$ Melnick and Willes, at 236-243.

${ }^{64}$ Union Electric Co. v. EPA, 427 U.S. 246, 268 (1976).

${ }^{65}$ See Ludwig Hartinger, Handbook of Effluent Treatment and Recycling for the Metal Finishing Industry 706 (2d ed. 1994)

${ }^{66}$ See generally Kenneth Wark and Cecil F. Warner, Air Pollution: Its Origin and Control 143-254 (1981).

${ }^{67}$ Wark and Warner, Air Pollution, at 234-235.

${ }^{68}$ See A. Denny Ellerman et. al., Markets for Clean Air: The U.S. Acid Rain Program 221-296 (2000). 
${ }^{69}$ See, for example, Scott R. Milliman and Raymond Prince, Firm Incentives to Adopt Technological Change in Pollution Control, 17 J. Envl. Econ. \& Manage. 247 (1989); David A. Malueg, Emission Credit Trading and the Incentive to Adopt New Pollution Abatement Technology, 16 J. Envl. Econ. \& Manage. 52 (1989).

${ }^{70}$ Often simply comparing an idealized command control regime with optimal, facility specific performance standards with trading regimes, as in Chulho Jung, Kerry Krutilla and Roy Boyd, Incentives for Advanced Pollution Abatement Technology at the Industry Level: An Evaluation of Policy Alternatives, 30 J. Envl. Econ. \& Manage. 95 (1996).

${ }^{71}$ That model is set forth in Juan-Pablo Montero, Prices vs. Quantities with Incomplete Enforcement, 85 J. Pub. Econ. 435 (2002). For present purposes, the simpler one-period model found in Juan-Pablo Montero, Prices versus Quantities with Incomplete Enforcement, Working Paper 99-009, Center for Energy and Environmental Policy Research, MIT (1999) suffices.

${ }^{72}$ Where $y=G^{-1}(q)$, we have that $C(q)=\int_{c}^{y} c d G$. By Leibnitzs Rule, it follows that $C^{\prime}(q)=y, C^{\prime}(0)=\underline{c}$, and (using the inverse function theorem) that $C^{\prime \prime}(q)=1 / g(y)$.

${ }^{73}$ For two such attempts, see Johnston, A Game Theoretic Analysis, supra and John M. de Figueiredo and Rui J. de Figueiredo, The Allocation of Resources by Interest Groups: Lobbying, Litigation, and Administrative Regulation, 4 Bus. \& Politics 161 (2002).

${ }^{74}$ The symmetric case is considered in some detail by Avinash Dixit, Strategic Behavior in Contests, 77 Amer. Econ. Rev. 891 (1987), who also makes the other standard assumptions regarding the shape of this function that are made here. A particular, simple functional form for such a contest function is the logit, $e_{i} /\left(e_{i}+e_{g}\right)$.

${ }^{75}$ For simplicity, this benefit is assumed to be constant across firms.

${ }^{76}$ The latter assertion can be verified by differentiating the regulatory first-order condition with respect to $e_{i *}$.

${ }^{77}$ This is what Dixit, 1987 refers to as a case where the firm is the overdog or favorite, but here this arises not because the regulatory contest is biased toward the firm, but because the firm has more at stake and so invests more in it.

${ }^{78}$ The reason is that while the firm can offset its compliance cost increase, in part, by increasing effort in the contest, all the government sees is increased firm effort, which it will not offset but actually exacerbate by lowering its own effort level in these circumstances.

${ }^{79}$ For a similar result, finding that firms with high compliance costs should not be inspected where inspection is costly, see Carol Adaire Jones and Suzanne Scotchmer, The Social Cost of Uniform Regulatory Standards in a Hierarchical Government, 19 J. Envl. Econ. \& Manage. 61, 64 (1990).

${ }^{80}$ The RECLAIM program in the Los Angeles basin, which allows firms to trade NOx and SOx emissions, relies upon such self-reporting. See South Coast Air Quality Management District, RECLAIM Program Three-Year Audit and Progress Report (1998); Scott L. Johnson and David M. Pekelney, Economic Assessment of the Regional Clean Air Incentives Market: A New Emissions Trading Program for Los Angeles, 72 Land Economics 277 (1996).

${ }^{81}$ Richard Toshiyuki Drury, Michael E. Belliveau, J. Scott Kuhn and Shipra Bansal, Pollution Trading and Environmental Injustice: Los Angeles failed Experiment in Air Quality Policy, 9 Duke Envtl. L. \& Poly F. 231, 259-260 (1999).

${ }^{82}$ For a description of the statutory basis and regulatory implementation of this program, 
see Robert W. Hahn and Gordon L. Hester, Where did all the Markets Go? An Analysis of EPAs Emissions Trading Program, 6 Yale J. Reg. 109, 113-118 (1989); Richard A. Liroff, Reforming Air Pollution Regulation: The Toil and Trouble of EPAs Bubble (1986).

${ }^{83}$ See Hahn and Hester, at 120-123.

${ }^{84}$ For more on the obstacles to offset trading, see Daniel J. Dudek and John Palmisano, Emissions Trading: Why is this Thoroughbred Hobbled?, 13 Colum. J. Envl. L. 217 (1988).

${ }^{85}$ See especially the chapters by Keohane and Newell in this volume.

${ }^{86}$ See Newell (this book); Robert W. Hahn and Robert N. Stavins, Incentive-Based Environmental Regulation: A New Era from an Old Idea, 18 Ecology L. Q. 1, 17 (1991).

${ }^{87}$ See Robert W. Hahn, Economic Prescriptions for Environmental Problems: How the Patient Followed the Doctors Orders, 3 J. Econ. Perspec. 95, 101-103 (1989)

${ }^{88}$ Codified as Clean Air Act 403, 42 U.S.C. 7651 b.

${ }^{89}$ See Keohane, [this volume]

${ }^{90}$ A. Denny Ellerman, Paul L. Joskow, Richard Schmalensee, Juan-Pablo Montero and Elizabeth M. Bailey, Markets for Clean Air: The U.S. Acid Rain Program 17 (2000).

${ }^{91}$ Ellerman et. al. Markets for Clean Air, 20-30

${ }^{92} \mathrm{~A}$ game described in great detail by Ellerman et. al., Markets for Clean Air, at 31-76.

${ }^{93}$ Title IV is roughly a closed system, in that most of the demand for permits has come from regulated firms themselves or permit brokers, rather than, say, environmentalists interested in reducing pollution

${ }^{94}$ A. Denny Ellerman, et. al., Markets for Clean Air, supra note at 31-76.

${ }^{95}$ Ellerman, et. al., at $23 /$

${ }^{96}$ Ellerman et. al. at 43 .

${ }^{97}$ Ellerman et. al., 43.

${ }^{98}$ Ellerman et. al. at 53-54.

${ }^{99}$ Ellerman, et. al. at 54 . They also explore, and find wanting, other potential explanatory variables, such as whether the state was an electoral swing state. Id. at 64-75.

${ }^{100}$ The extension is from the world of the model - which assumes constant marginal cost of compliance for each facility (assumed to be a firm), but differences in this cost across facilities - to a world where each facility has increasing marginal abatement cost. In a model where each facility has increasing marginal abatement cost, the equilibrium under bargained CAC may be thought of as one in which the low cost firms are those that have a lower cost of achieving a given discrete pollution reduction, but after achieving that reduction have been pushed so far out their marginal cost curves that the marginal cost of any further discrete reduction is higher to them than to the previously unregulated, formerly high cost firms.

${ }^{101}$ For a discussion of the many perverse incentives created by this regime, see Byron Swift, How Environmental Laws Work: An Analysis of the Utility Sector's Response to Regulation of Nitrogen Oxides and Sulfur Dioxide under the Clean Air Act, 14 Tul. Envtl. L. J. 309 (2001).

${ }^{102}$ Ellerman, et. al., at 53.

${ }^{103}$ See, for example, Sierra Club, Facts about the Bush Administration's Plan to Weaken the Clean Air Act, available at www.sierraclub.org/cleanair/clear_skies.asp.

Johnston, Tradable Pollution Permits 


\section{References}

[1] Bruce A. Ackerman and Richard B. Stewart, Reforming Environmental Law, 37 Stan. L. Rev. 1333 (1985).

[2] T.H. Tietenberg, Emissions Trading: An Exercise in Reforming Pollution Policy (1985).

[3] Charles D. Kolstad, Environmental Economics 155-177 (2000).

[4] Juan-Pablo Montero, Testing the Efficiency of a Tradeable Permits Market (Draft, Sept. 6, 2002).

[5] Paul Joskow, Richard Schmalensee and Elizabeth Bailey, The Market for Sulfur Dioxide Emissions, 88 Amer. Econ. Rev. 669 (1998).

[6] Gert Tinggaard Svendsen, Public Choice and Environmental Regulation: Tradable Permit Systems in the United States and CO2 Taxation in Europe 71-132 (1998).

[7] Robert W. Hahn and Gordon L. Hester, Where did all the Markets Go? An Analysis of EPAs Emissions Trading Program, 6 Yale J. Reg. 109 (1989).

[8] A. Denny Ellerman et. al., Markets for Clean Air: The U.S. Acid Rain Program (2000).

[9] Gloria E. Hellfand, Standards versus Standards: The Effects of Different Pollution Restrictions, 81 Amer. Econ. Rev. 622 (1991).

[10] Jason Scott Johnston, A Game-Theoretic Analysis of Alternative Institutions for Regulatory Cost-Benefit Analysis, 150 U. Pa. L. Rev. 1343, 1395-1401 (2002).

[11] Louis Kaplow and Steven Shavell, Property Rules versus Liability Rules, 109 Harv. L. Rev. 713, 751-752 (1996).

[12] Clifford S. Russell, Achieving Air Pollution Goals in Three Different Settings, in To Breathe Freely: Risk, Consent and Air 233, 254 (Mary Gibson, ed. 1985). 
[13] Howard Latin, Ideal versus Real Regulatory Efficiency: Implementation of Uniform Standards and "Fine-Tuning" Regulatory Reforms, 37 Stan. L. Rev. 1267, 1314 (1985).

[14] Jason Scott Johnston, The Promise and Limits of Voluntary Management-Based Regulatory Reform: An Analysis of EPAs Strategic Goals Program, forthcoming in Leveraging the Private Sector (Cary Coglianese and Jennifer Nash, eds., 2005).

[15] Howard Latin, The Feasibility of Occupational Health Standards: An Essay on Legal Decisionmaking Under Uncertainty, 78 N.W.U. L. Rev. 583, 588, 600-602, 611-17 (1983).

[16] Robert V. Zener, Guide to Environmental Law 90-91 (1981).

[17] Zamanky \& Zerbe, Adjudicatory Hearings as Part of the NPDES Permit Process, 9 Ecol. L. Q. 1, 13, 17 (1980).

[18] P.D. Reed, Industry Effluent Limitations Program in Dissarray as Congress Prepares for Debate on Water Act Amendments, 12 Envl L. Rptr. _- (1982).

[19] William F. Pedersen, Turning the Tide on Water Quality, 15 Ecology L. Q. 69, 85 (1988).

[20] Daniel Farber, Taking Regulatory Slippage Seriously []

[21] George Hays and Nadia Wetzler, Federal Recognition of Variances: A Window into the Turbulent Relationship between Science and Law under the Clean Air Act, 13 J. Envtl. L. \& Litig. 115, 127-141(1998).

[22] Marc Melnick and Elizabeth Willes, Watching the Candy Store: EPA Overfiling of Local Air Pollution Variances, 20 Ecol. L. Q. 207 (1993).

[23] Ludwig Hartinger, Handbook of Effluent Treatment and Recycling for the Metal Finishing Industry 706 (2d ed. 1994).

[24] Kenneth Wark and Cecil F. Warner, Air Pollution: Its Origin and Control 143-254 (1981). 
[25] Scott R. Milliman and Raymond Prince, Firm Incentives to Adopt Technological Change in Pollution Control, 17 J. Envl. Econ. \& Manage. 247 (1989).

[26] David A. Malueg, Emission Credit Trading and the Incentive to Adopt New Pollution Abatement Technology, 16 J. Envl. Econ. \& Manage. 52 (1989).

[27] Chulho Jung, Kerry Krutilla and Roy Boyd, Incentives for Advanced Pollution Abatement Technology at the Industry Level: An Evaluation of Policy Alternatives, 30 J. Envl. Econ. \& Manage. 95 (1996).

[28] Juan-Pablo Montero, Prices vs. Quantities with Incomplete Enforcement, 85 J. Pub. Econ. 435 (2002).

[29] Juan-Pablo Montero, Prices versus Quantities with Incomplete Enforcement, Working Paper 99-009, Center for Energy and Environmental Policy Research, MIT (1999).

[30] John M. de Figueiredo and Rui J. de Figueiredo, The Allocation of Resources by Interest Groups: Lobbying, Litigation, and Administrative Regulation, 4 Bus. \& Politics 161 (2002).

[31] Avinash Dixit, Strategic Behavior in Contests, 77 Amer. Econ. Rev. 891 (1987).

[32] South Coast Air Quality Management District, RECLAIM Program Three-Year Audit and Progress Report (1998).

[33] Carol Adaire Jones and Suzanne Scotchmer, The Social Cost of Uniform Regulatory Standards in a Hierarchical Government, 19 J. Envl. Econ. \& Manage. 61 (1990).

[34] Scott L. Johnson and David M. Pekelney, Economic Assessment of the Regional Clean Air Incentives Market: A New Emissions Trading Program for Los Angeles, 72 Land Economics 277 (1996).

[35] Richard Toshiyuki Drury, Michael E. Belliveau, J. Scott Kuhn and Shipra Bansal, Pollution Trading and Environmental Injustice: Los Angeles failed Experiment in Air Quality Policy, 9 Duke Envtl. L. \& Poly F. 231, 259-260 (1999). 
[36] Richard A. Liroff, Reforming Air Pollution Regulation: The Toil and Trouble of EPAs Bubble (1986).

[37] Daniel J. Dudek and John Palmisano, Emissions Trading: Why is this Thoroughbred Hobbled?, 13 Colum. J. Envl. L. 217 (1988).

[38] Robert W. Hahn and Robert N. Stavins, Incentive-Based Environmental Regulation: A New Era from an Old Idea, 18 Ecology L. Q. 1, 17 (1991).

[39] Robert W. Hahn, Economic Prescriptions for Environmental Problems: How the Patient Followed the Doctors Orders, 3 J. Econ. Perspec. 95, 101-103 (1989).

[40] Byron Swift, How Environmental Laws Work: An Analysis of the Utility Sector's Response to Regulation of Nitrogen Oxides and Sulfur Dioxide under the Clean Air Act, 14 Tul. Envtl. L. J. 309 (2001).

Johnston, Tradable Pollution Permits 